\title{
Case Report \\ Dysphagia after Colon Interposition Graft for Esophageal Carcinoma
}

\author{
C. Spitali, K. De Vogelaere, and G. Delvaux \\ Department of Surgery, UZ Brussel, Laarbeeklaan 101, 1090 Jette, Belgium \\ Correspondence should be addressed to C. Spitali, carmelaspitali@hotmail.com \\ Received 24 September 2012; Accepted 10 October 2012 \\ Academic Editors: A. Mima and Y. Nagashima
}

Copyright ( 2012 C. Spitali et al. This is an open access article distributed under the Creative Commons Attribution License, which permits unrestricted use, distribution, and reproduction in any medium, provided the original work is properly cited.

Colon interposition is an established technique for esophageal reconstruction. We describe the case of primary adenocarcinoma arising in a colonic interposition graft that was performed after total esophagectomy for recurrence adenocarcinoma derived from the Barrett esophagus.

\section{Introduction}

In 1911, Kelling and Vuillet described the anatomic and surgical bases for the use of colon as replacement for the esophagus $[1,2]$.

Early postoperative complications are common, including necrosis of the transplant, leaks, fistulae, and strictures at the anastomoses. Late complications are rare. We describe an unusual late complication of a primary adenocarcinoma arising in the interposed colon after a right colonic bypass in a patient with adenocarcinoma derived from the Barrett esophagus.

\section{Case Report}

A 66-year-old male presented with history of progressive dysphagia for solid food.

Six years ago, he underwent a proximal gastrectomy and distal esophagectomy for adenocarcinoma derived from Barrett esophagus. Four years later, an esophagoscopy revealed a recurrence at the anastomotic site. A biopsy of the lesion showed a well-differentiated adenocarcinoma of the esophagus. Further investigation showed no evidence of metastatic disease, and a three-stage procedure with total esophagectomy was performed. The right-sided colon from the ileocaecal junction to the mid-transverse colon was used in a prevertebral position to reestablish continuity between the cervical esophagus and the remnant of the pyloric antrum. Histological examination revealed a pT2N0 lesion, and the patient recovered well without major complications. Two years after this intervention, the patient developed a progressive dysphagia for solid food. Endoscopy showed a circumferential mass arising from the colon (Figure 1), and biopsy confirmed a colonic type of adenocarcinoma. Barium swallow revealed the circumferential tumor at the ileocaecal junction (Figure 2). Further investigation with PET scan (Figure 3) demonstrated a tumor paravertebral right at the level of D7-D9 and no metastatic disease. Reintervention was proposed to the patient. Through a right thoracotomy an ileocaecal resection with end-to-end anastomosis was performed with preservation of the "cardial" marginal arcades artery to prevent necrosis of the proximal ileal segment.

Histological examination revealed a pT2 tumor of the colon and one normal lymphenode.

The patient recovered well with a good functional conduit and remained disease-free now at 24 months.

\section{Discussion}

The potential use of a pedicled segment of colon to bypass esophageal pathology was first described since the early sixthies. Colonic grafts have been used in the treatment of both benign (e.g., esophageal atresia and stricture) and malignant oesophageal pathology (e.g., cancer of esophagus and cardia). 


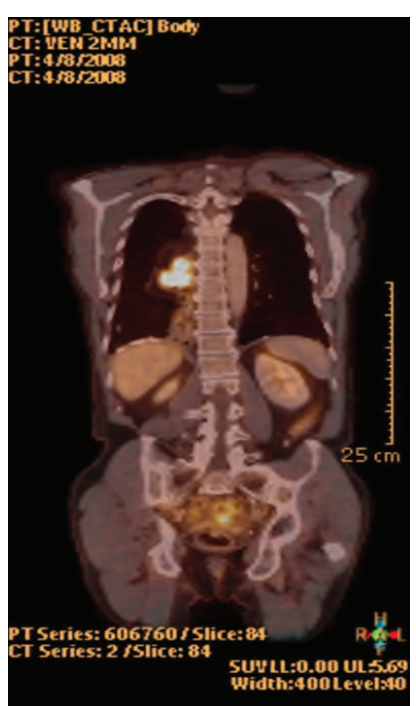

Figure 1: The PET-CT showed a tumor paravertebral right at the level of D7-D9 and no metastatic disease.

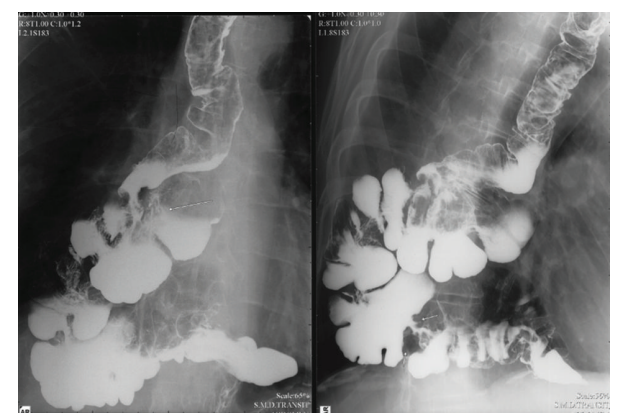

Figure 2: Barium swallow revealed a circumferential mass arising from the colon.

Early complications of this procedure are common, including graft necrosis, anastomotic leak, fistulae, and stricture of the anastomosis [3-5]. Other unusual sequelae, including paracolic hiatal herniation and herniation of small intestine through the mesocolon have been reported [6].

Late complications are rare: progressive fibrostenosis of the graft, peptic colitis with ulceration of the colonic segment, gastrocolic reflux, and colopericardial and colobronchial fistula were described $[4,7]$. The progressive development of diverticular disease in colon interposition has also been reported in previous literature by Nelson and Grayer [8].

Primary carcinoma arising in a colonic interposition is obviously rare. Review of literature showed only 11 cases (Table 1). These cases describe the use of colonic grafts in the treatment of both benign (e.g., esophageal atresia and stricture) and malignant oesophageal pathology (e.g., cancer of esophagus and cardia). Table 2 shows the pathology in the colonic graft at long term and the treatment.

The late development of dysphagia in a patient with a colonic interposition graft should be examined seriously.

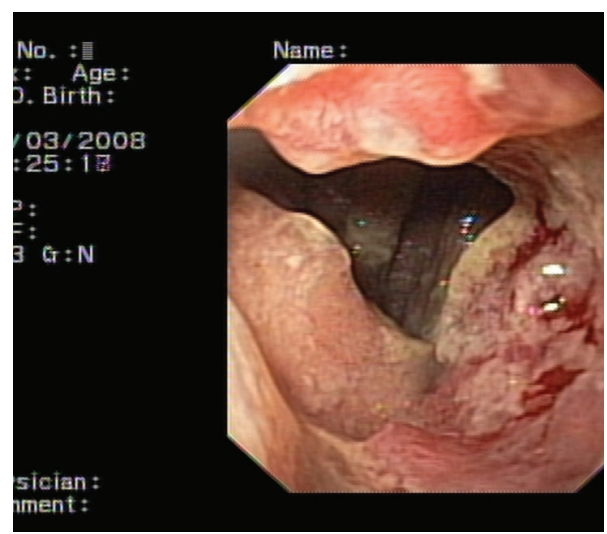

FIgURE 3: Endoscopy showed circumferential tumor at the ileocaecal junction.

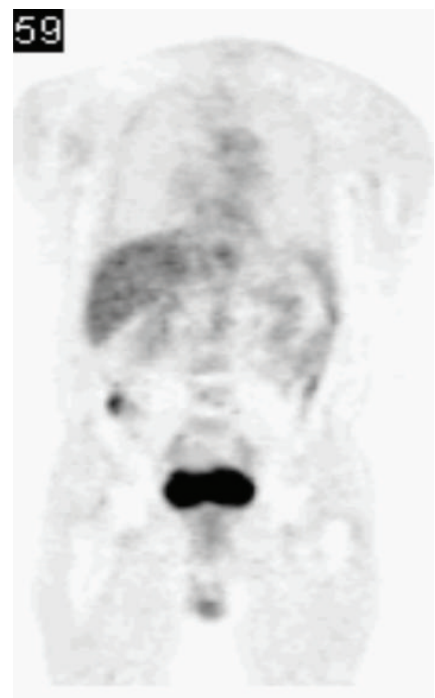

Figure 4: Pre-existing lesion of the colon missed on PET-CT.

Contrast studies of colonic grafts can be difficult to interpret due to altered anatomy. Barium esophagography has the advantage of providing functional evaluation of the graft and integrity of the conduit anastomosis. However, radiographic evaluations and interpretations of the interposed colon may be difficult if there is unfamiliarity with the various surgical procedures and the postoperative appearances $[10,11]$.

Endoscopy with biopsy should therefore be considered.

Computed tomography plays a limited role in the examination of the interposed colon. It may provide valuable evaluation of the extent of the tumor invasion and for the staging preoperatively.

So far, there is no definable association between the primary carcinoma of the esophagus or stomach and the colon cancer $[20,21]$.

As more patients are followed over a long period, the later sequelae of colon interposition will become more evident. Whether the interposed segment of colon is more likely to develop carcinoma than a normally sited segment of colon remains to be seen. 


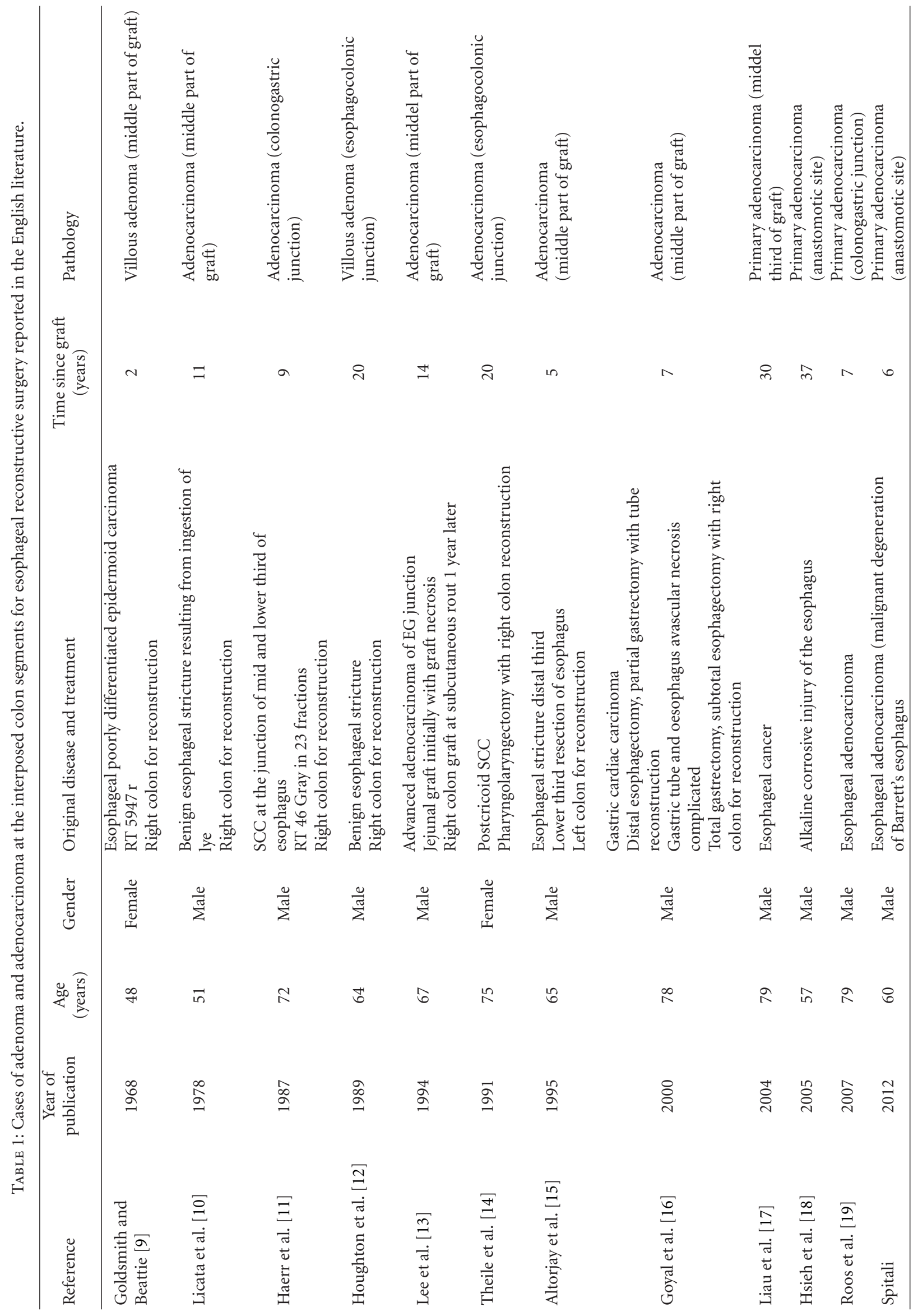


TABLE 2: Treatment of adenoma and adenocarcinoma at the interposed colon segments for esophageal reconstructive surgery.

\begin{tabular}{|c|c|c|c|}
\hline Reference & Year of publication & Pathology & Treatment \\
\hline Goldsmith and Beattie [9] & 1968 & Villous adenoma (middle part of graft) & $\begin{array}{l}\text { Segmental resection distal colon bypass } \\
\text { and cologastrostomy }\end{array}$ \\
\hline Licata et al. [10] & 1978 & Adenocarcinoma (middel part of graft) & Not specified \\
\hline Haerr et al. [11] & 1987 & $\begin{array}{l}\text { Adenocarcinoma (colonogastric } \\
\text { junction) }\end{array}$ & $\begin{array}{l}\text { Radio and chemotherapy because of } \\
\text { tumor unresectable (invasion of sternum } \\
\text { and mediastinum) }\end{array}$ \\
\hline Houghton et al. [12] & 1989 & $\begin{array}{l}\text { Villous adenoma } \\
\text { (esophagocolonic junction) }\end{array}$ & $\begin{array}{l}\text { Resection colonic interposition and } \\
\text { gastric interposition }\end{array}$ \\
\hline Lee et al. [13] & 1994 & Adenocarcinoma (middel part of graft) & $\begin{array}{l}\text { Resection lower part colonic graft and } \\
\text { reanastomosis with jejunum }\end{array}$ \\
\hline Theile et al. [14] & 1991 & $\begin{array}{l}\text { Adenocarcinom (esophagocolonic } \\
\text { junction) }\end{array}$ & $\begin{array}{l}\text { Resection upper part colonic graft and } \\
\text { free jejunal graft }\end{array}$ \\
\hline Altorjay et al. [15] & 1995 & $\begin{array}{l}\text { Adenocarcinoma } \\
\text { (middle part of graft) }\end{array}$ & $\begin{array}{l}\text { Resection interposed colon and } \\
\text { Roux-en-Y esophagojejunostomy }\end{array}$ \\
\hline Goyal et al. [16] & 2000 & $\begin{array}{l}\text { Adenocarcinoma } \\
\text { (middle part of graft) }\end{array}$ & \\
\hline Liau et al. [17] & 2004 & $\begin{array}{l}\text { Primary adenocarcinoma } \\
\text { (middel third of graft) }\end{array}$ & Chemotherapy \\
\hline Hsieh et al. [18] & 2005 & $\begin{array}{l}\text { Primary adenocarcinoma } \\
\text { (anastomotic site) }\end{array}$ & $\begin{array}{l}\text { Resection whole colonic graft, cervical } \\
\text { esophagostomy, and feeding gastrostomy }\end{array}$ \\
\hline Roos et al. [19] & 2007 & $\begin{array}{l}\text { Primary adenocarcinoma } \\
\text { (colonogastric junction) }\end{array}$ & $\begin{array}{l}\text { Resection colon graft, cervical } \\
\text { oesophagostomy, and feeding } \\
\text { jejunostomy }\end{array}$ \\
\hline Spitali & 2012 & $\begin{array}{l}\text { Primary adenocarcinoma } \\
\text { (anastomotic site) }\end{array}$ & $\begin{array}{l}\text { Ileocecal resection and end-to-end } \\
\text { anastomosis }\end{array}$ \\
\hline
\end{tabular}

In our case, a pre-existing lesion of the colon was indeed missed: during the examinations preoperatively an existing little spot was not remarked on PET scan (Figure 4). This was probably a tubulovillous adenoma of the colon. It is clear that examination of the colon before using it as a graft to exclude colonic disease is preferred.

On the other hand, to rule out the existence of a second primary cancer arising in the interposed colonic mucosa, an endoscopy of the colonic graft should be considered regularly as follow up in the postoperative period.

In summery, malignancy arising in the interposed colon graft is rare.

Total colonoscopy should be included in the preoperative setting when interposition of colonic segment needs to be used for replacement of the esophagus. This is to detect unexpected lesions.

Development of new symptoms in a patient with a colonic graft should always be taken seriously and investigated.

\section{References}

[1] G. E. Kelling, “Oesophagoplastik mit hilfeder querkolon,” Das Zentralblatt für Chirurgie, vol. 38, pp. 1209-1212, 1911.

[2] H. Vuillet, "De l'oesophagoplastiek et des diverses modifications," Semaine de la Méditerranée, vol. 31, pp. 529-534, 1911.
[3] T. C. Larson, L. S. Shuman, H. I. Libshitz, and M. J. McMurtrey, "Complications of colonic interposition," Cancer, vol. 56, no. 3, pp. 681-690, 1985.

[4] R. Belsey, Replacement of the Esophagus With the Colon. General Thoracic Surgery, 2000.

[5] R. W. Postlethwait, W. C. Sealy, M. L. Dillon, and W. G. Young, "Colon interposition for esophageal substitution," Annals of Thoracic Surgery, vol. 12, no. 1, pp. 89-109, 1971.

[6] R. P. Sterling, R. C. Kuykendall, M. J. Carmichael, and K. Khalil, "Unusual sequelae of colon interposition for esophageal reconstruction: late obstruction requiring reoperation," Annals of Thoracic Surgery, vol. 38, no. 3, pp. 292-295, 1984.

[7] D. C. Mullen, R. W. Postlethwait, and M. L. Dillon, "Complications of substernal colon interposition," American Surgeon, vol. 36, no. 2, pp. 80-84, 1970.

[8] A. M. Nelson and D. I. Grayer, "Development of diverticular disease in the transplanted colon," American Journal of Gastroenterology, vol. 72, no. 6, pp. 660-661, 1979.

[9] H. S. Goldsmith and E. J. Beattie, "Malignant villous tumor in a colon bypass," Annals of Surgery, vol. 167, no. 1, pp. 98-100, 1968.

[10] A. A. Licata, P. Fecanin, and R. Glowitz, "Metastatic adenocarcinoma from oesophageal colonic interposition," The Lancet, vol. 1, no. 8058, article 285, 1978.

[11] R. W. Haerr, E. M. Higgins, C. H. Seymore, and A. M. ElMahdi, "Adenocarcinoma arising in a colonic interposition following resection of squamous cell esophageal cancer," Cancer, vol. 60, no. 9, pp. 2304-2307, 1987. 
[12] A. D. Houghton, M. Jourdan, and I. McColl, "Dukes A carcinoma after colonic interposition for oesophageal structure," Gut, vol. 30, no. 6, pp. 880-881, 1989.

[13] S. J. Lee, C. B. Koay, H. Thompson, A. R. Nicolaides, and A. R. Das Gupta, "Adenocarcinoma arising in an oesophageal colonic interposition graft," Journal of Laryngology and Otology, vol. 108, no. 1, pp. 80-83, 1994.

[14] D. E. Theile, B. M. Smithers, R. W. Strong, and C. J. Windsor, "Primary adenocarcinoma in a colonic oesophageal segment," Australian and New Zealand Journal of Surgery, vol. 61, no. 12, pp. 953-955, 1991.

[15] A. Altorjay, J. Kiss, A. Voros, I. Szanto, and A. Bohak, "Malignant tumor developed in colon-esophagus," HepatoGastroenterology, vol. 42, no. 6, pp. 797-799, 1995.

[16] M. Goyal, D. H. Bang, and L. E. Cohen, "Adenocarcinoma arising in interposed colon," Diseases of the Colon and Rectum, vol. 43, no. 4, pp. 555-558, 2000.

[17] C. T. Liau, S. Hsueh, and K. M. Yeow, "Primary adenocarcinoma arising in esophageal colon interposition: report of a case," Hepato-Gastroenterology, vol. 51, no. 57, pp. 748-749, 2004.

[18] Y. S. Hsieh, K. M. Huang, T. J. Chen, Y. H. Chou, and C. M. OuYang, "Metachronous adenocarcinoma occurring at an esophageal colon graft," Journal of the Formosan Medical Association, vol. 104, no. 6, pp. 436-440, 2005.

[19] D. Roos, O. Busch, and O. van Lanschot, "Primair coloncarcinoma in een coloninterponaat na oesofagusresectie," Nederlands Tijdschrift voor Geneeskunde, vol. 151, no. 38, pp. 2111-2113, 2007.

[20] J. T. Goodner and W. L. Watson, "Cancer of the esophagus; its association with other primary cancers," Cancer, vol. 9, no. 6, pp. 1248-1252, 1956.

[21] E. Lynge, O. M. Jensen, and B. Carstensen, "Second cancer following cancer of the digestive system in Denmark, 194380," National Cancer Institute Monograph, vol. 68, pp. 277-308, 1985. 


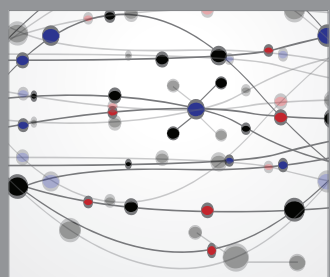

The Scientific World Journal
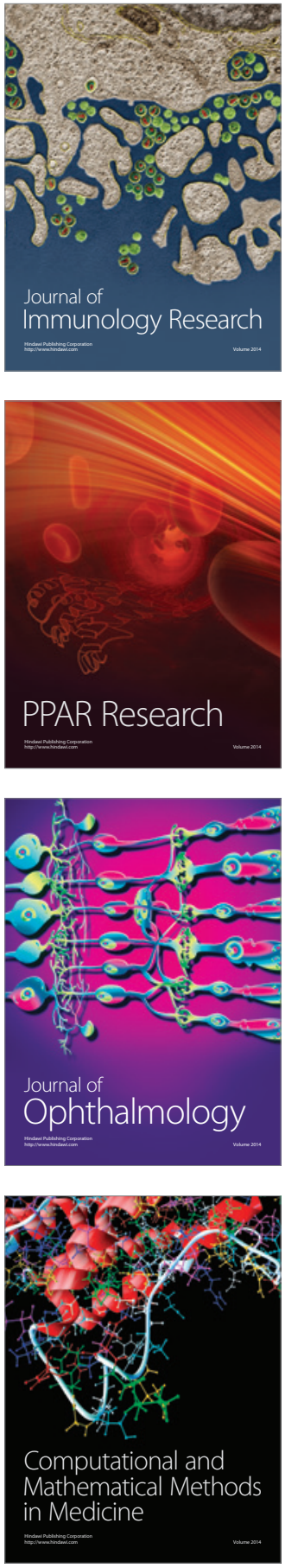

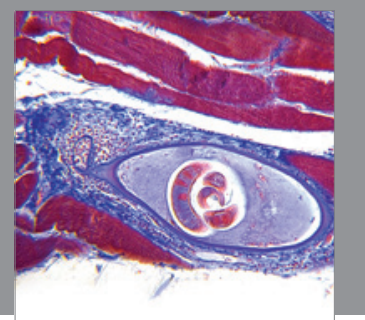

Gastroenterology

Research and Practice
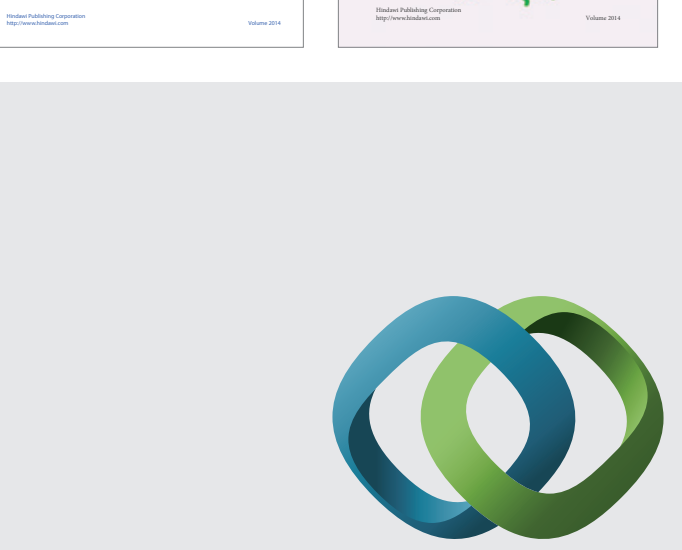

\section{Hindawi}

Submit your manuscripts at

http://www.hindawi.com
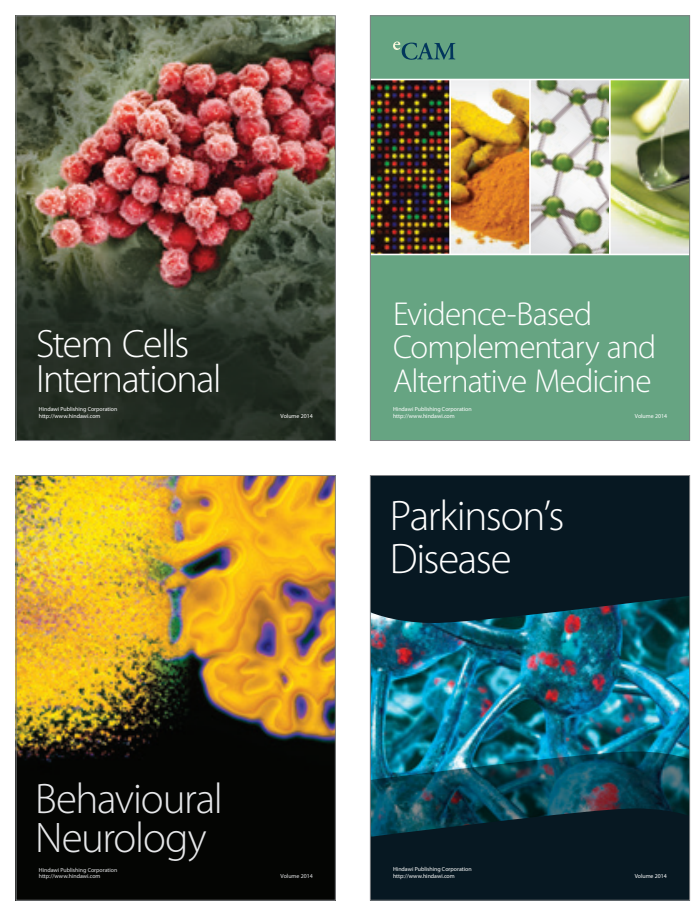

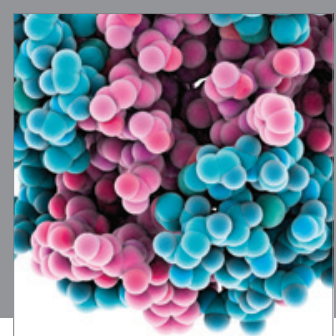

Journal of
Diabetes Research

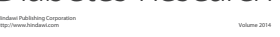

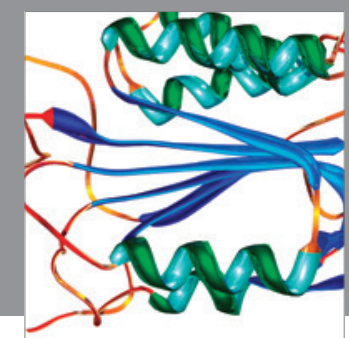

Disease Markers
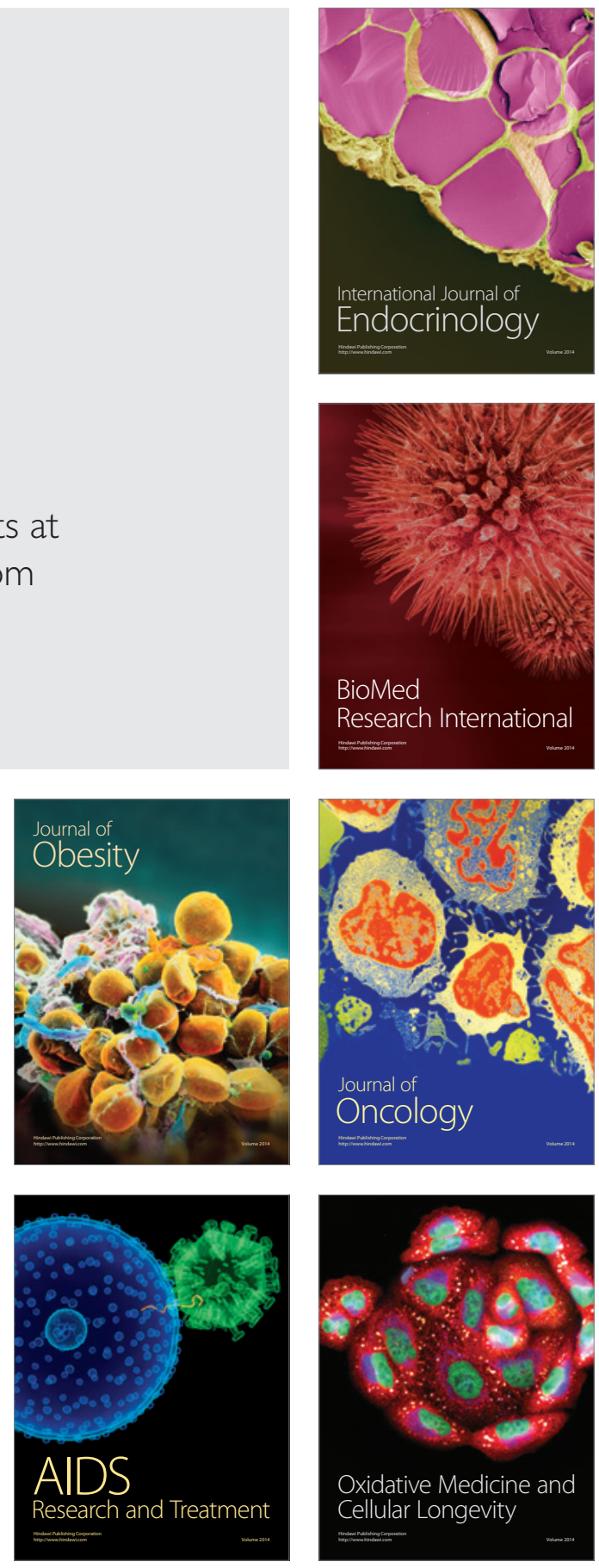